ДОМБРОВСЬКА О.П., ДОМБРОВСЬКИЙ А.Г., СУМСЬКА О.П. Херсонський національний технічний університет

\title{
ОСНОВНІ ЗАСОБИ ДЕРЖАВНОГО РЕГУЛЮВАННЯ У СФЕРІ ТЕЛЕКОМУНІКАЩЇ̈
}

\author{
ДОМБРОВСКАЯ Е.П., ДОМБРОВСКИЙ А.Г., СУМСКАЯ О.П. \\ Херсонский национальний технический унивверситет \\ ОСНОВНЫЕ СРЕДСТВА ГОСУДАРСТВЕННОГО РЕГУЛИРОВАНИЯ \\ В СФЕРЕ ТЕЛЕКОММУНИКАЦИИ
}

\author{
DOMBROVSKA O.P., DOMBROVSKYI A.G., SUMSKA O.P. \\ Kherson National Technical University \\ BASIC MEANS OF THE STATE REGULATION IN THE \\ TELECOMMUNICATION
}

\author{
https://doi.org/10.36910/6775-2310-5283-2019-12-30
}

Мета. Дослідження державної нормативно-законодавчої бази у сфері телекомунікаційних послуг з метою їх ефективного розвитку.

Методика. При дослідженні використовували базу діючих державних $і$ галузевих стандартів та інших нормативних документів, які визначають вимоги до телекомунікаційних мереж, їх технічних засобів та якості телекомунікаційних послуг.

Результати. Із-за відсутності необхідних національних стандартів під час проектування, сертифікаиії, експлуатації мереж та обладнання зв'язку в Україні иироко використовуються рекомендації ITU $i$ стандарти ETSI. Робота в міжнародних організаціях на етапах обговорення та ухвалення проектів стандартів може полегшити та прискорити розробку національних стандартів шляхом переносу стандартів, отримавши статус міжнародних або європейських, на начіональний рівень. Для того, щоб визначити, як необхідно сьогодні $і$ в найближчому майбутньому формувати політику стандартизації украӥнських мереж, потрібно врахувати світовий досвід. Підключення до мережі загального користування повинно відбуватися з використанням основних вимог із забезпечення безпеки, інтегрованості мережі, захисту даних тощо, які викладені в Директивах Європейської комісії (1995/5/СC, 98/10/ЄС i ін.). Ці основні вимоги повинні бути конкретизовані відповідними стандартами. В країнах $Є C$ сьогодні існує перелік гармонізованих технічних норм (Перелік 2002/3 331/04), які охоплюють такі напрямки: орендовані лінії, доступ до мереж і міжмережна взаємодія, багатооператорський доступ до мережі на абонентському відділі, надання послуг, захист даних, мережа для розподілу послуг мовлення. Під час дослідження виявлено, щчо на українському ринку телекомунікацій діє багато стандартів, розроблених ще під час існування колишнього Радянського Союзу. Із-за відсутності фінансування в достатньому обсязі відсутні національні стандарти з багатьох нових технологій (WDM, IP, OMTS, CDMA тощо). Для забезпечення ефективного розвитку телекомунікаційних послуг слід створити і поступово впровадити нормативно-правову базу із забезпечення питань технічного та 
криптографічного захисту

інформації,

гармонізованого

європейськими

$m a$ міжнародними стандартами.

Наукова новизна. Встановлено та обтрунтовано необхідність гармонізачії вимог державних стандартів з вимогами міжнародних нормативних документів, а також удосконалювання системи стандартизації телекомунікаційних послуг з урахуванням світового досвіду.

Практична значимість. Докладно проаналізовано й розкрито основні засоби державного регулювання та захисту ринку телекомунікацій. Проведений аналіз виявив напрямки розвитку системи стандартизації телекомунікаційних послуг.

Ключові слова: телекомунікації, стандартизачія, телекомунікаційні послуги, стандарти, Інтернет.

Постановка проблеми у загальному вигляді та її зв'язок із важливими науковими чи практичними завданнями. Об'єктивні процеси розвитку економічної системи призвели до того, що останнім часом в Україні приділяється все більше уваги сектору телекомунікацій, що сьогодні $\epsilon$ основою нової економіки на Заході й одним із найперспективніших і швидко зростаючих сегментів вітчизняної економіки. Розвиток сучасних економічних систем має місце в умовах постійної активізації процесів глобалізації. Масштаб, характер, структура, якісні і кількісні параметри включення національних економічних систем у ці процеси сьогодні вже асоціюються 3 об’єктивними показниками розвитку сучасних держав, ключовими детермінантами їхнього майбутнього. Закон України «Про телекомунікації» визначає телекомунікації як передавання, випромінювання або приймання знаків, сигналів, письмового тексту, зображень та звуків або повідомлень будь-якого роду по радіо, проводових, оптичних або інших електромагнітних системах. Основними сегментами телекомунікаційних послуг є:

- мобільний зв'язок - питома вага в останні роки складає понад 66 \% ;

- фіксований зв'язок - питома вага в загальному обсязі доходів поступово знижується і склала понад 17 \% в 2017 році;

- широкосмуговий доступ (ШСД) (комп’ютерний зв'язок) - питома вага постійно збільшується і в 2017 році склала понад $11 \%$.

Аналіз останніх досліджень, у яких започатковано вирішення проблеми. Телекомунікації в Україні стрімко розвивалися у пореформений період 1997-2017 роках. Український ринок телекомунікаційних послуг як одна із важливих складових інноваційної економіки демонструє високі темпи зростання, що випереджають темпи зростання економіки в цілому: частка галузі «Зв’язок» в структурі ВВП постійно збільшується, за даними Держкомстату вона зросла у 2015-2017 роках з 3,1\% до 6,5 \%. Особливого прискорення набувають послуги по окремим сегментам зазначеного ринку. 
Темпи зростання послуг мобільного зв'язку та Інтернет-послуг красномовно засвідчують, що роль цього сектора в економіці України неухильно зростає (рівень проникнення мобільного зв'язку в Україні досяг 120,1\% у 2016 р. порівняно з $72 \%$ у США, а темп зростання абонентської бази в вітчизні склав $117 \%$ у 2016 році, також у 2017 році темп зростання вкладання всіх прямих іноземних інвестицій (ПІІ) економіки країни склав 7 \% [1].

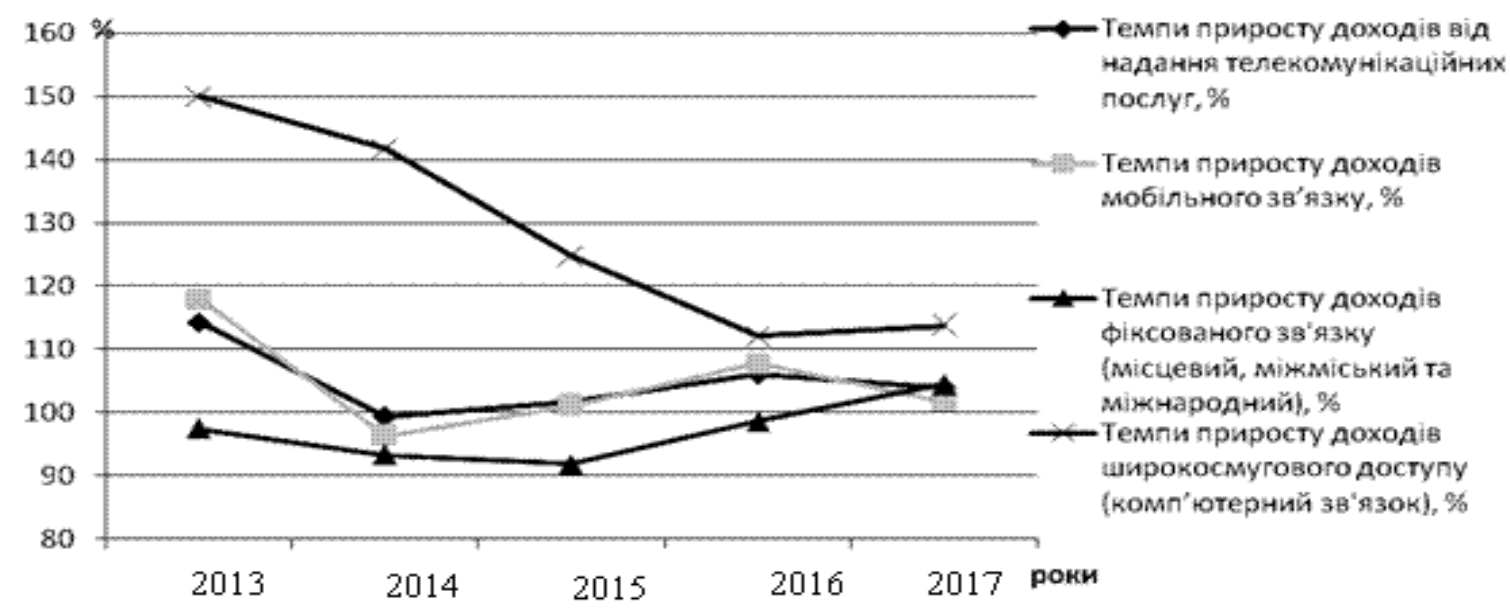

Рис. 1. Темпи приросту доходів галузі зв'язку

У 2017 році оператори усіх форм власності надали послуг зв'язку на 46,1 млрд. грн., з них 18 млрд. грн. - від послуг, наданих населенню.

Середня українська сім'я витратила на послуги зв'язку в середньому на рік близько 990 грн. або 83 грн. на місяць, з них половина витрати на рухомий (мобільний зв'язок), чверть — фіксований телефонний зв'язок, $10 \%$ послуги з передачі даних та надання доступу до мережі Інтернет і менше 3 \% - послуги поштового зв'язку.

Органом регулювання у сфері телекомунікацій за статтею 17 Закону України «Про телекомунікації» визначається Національна комісія 3 питань регулювання зв'язку України. Основними засобами державного регулювання у сфері телекомунікації $є$ : нагляд за ринком телекомунікації, ліцензування діяльності у сфері телекомунікації, визначення принципів взаємоз'єднання телекомунікаційних мереж, визначення основ розвитку та надання загальнодоступних телекомунікаційних послуг, регулювання тарифів i розподіл номерного ресурсу.

Телекомунікації України виконують три основні функції:

a) надання важливих послуг індивідуального споживання (міжперсональне телеспілкування, інформаційне самозабезпечення, 
самоосвіта, відпочинок, розваги тощо);

б) складання частини виробничої інфраструктури (бізнес-зв'язки, реклама, брокераж, просторово-рознесені виробничі процеси тощо);

в) участь у вдосконаленні соціальної організації суспільства (електронне врядування, осередки громадянського суспільства, екстрена та медична допомога тощо).

Функція індивідуального споживання послуг зв'язку повинна бути піднята до рівня аналогічного споживання в країнах - членах СС. Без цього громадяни України не зможуть себе відчувати рівними з громадянами інших країн СС як у спілкуванні, так і в організації персональної інформаційнокомунікаційної сфери. Недостатній рівень споживання послуг зв'язку, особливо їх сучасних видів - мобільного та Інтернет, - можуть бути істотною складовою невдоволення населення від вступу до ЄС. Залишати основну масу українських громадян 3 недорозвиненою системою стаціонарного телефонного зв'язку і з початковим рівнем забезпечення мобільним зв'язком і Інтернет означає позбавити їх права на сучасні загальнодоступні види зв'язку, права, вже реалізованого в країнах ЄC.

Отже, високі вимоги до основних державотворчих функцій українських телекомунікацій перед вступом до ЄС та низький їх сьогоднішній рівень розвитку ставить на порядок денний необхідність розробки і прийняття стратегії швидкого кількісного розвитку (у 3-10 разів упродовж 10-15 років) базових видів зв’язку українських телекомунікацій.

Найважливішими напрямками політики у цій сфері є:

- реалізація передових розробок вітчизняних учених та їх впровадження у виробництво;

- більш осмислений захист авторських розробок вітчизняних вчених в сфері технологій, а також керування в цій сфері за допомогою висококваліфікованого персоналу державних службовців;

- взаємодія науки, навчання та виробництва;

- відкритий конкурсний відбір виконавців держзамовлень;

- модернізація інформаційно-телекомунікаційних систем 3 чітким пріоритетом вітчизняних розробок;

- участь в обговорені та розробці міжнародних стандартів (до числа основних міжнародних організацій, що працюють в області стандартизації зв'язку, варто віднести Міжнародний союз електрозв'язку (МСЕ), Міжнародний електротехнічний комітет (МЕК), Європейський інститут стандартизації електрозв'язку ( 
стандартизації (MOC) і багато інших);

- подальше удосконалювання системи стандартизації та сертифікації продукції вітчизняних і зарубіжних розробників та виробників.

Цілі статті. Основне завдання дослідження полягає в оцінці сучасного стану стандартизації у сфері телекомунікацій, розгляді норативнозаконодавчої бази телекомунікаційних послуг в Україні та світі й доведення необхідності створення єдиної системи державних і галузевих стандартів та інших нормативних документів, які визначають вимоги до телекомунікаційних мереж, їх технічних засобів та якості телекомунікаційних послуг, а також гармонізації цих вимог з вимогами міжнародних нормативних документів. На міжнародному рівні нормування та стандартизація у галузі зв'язку здійснюються Регламентом радіозв'язку, Рекомендаціями Міжнародного союзу електрозв'язку (ITU), стандартами Свропейського інституту стандартів зі зв'язку (ETSI), стандартами різних міжнародних та регіональних експлуатаційних організацій. В окремо взятих державах існують національні організації зі стандартизації (НОC), які координують розробку національних нормативних документів [2].

Таблиця 1

Нормативна документація, яка визначає систему стандартизації галузі зв'язку України

\begin{tabular}{|l|l|}
\hline Номер документа & \multicolumn{1}{|c|}{ Назва нормативного документа } \\
\hline КНД 45-001-98 & Система стандартизації галузі зв’язку України. Основні положення \\
\hline КНД 45-003-98 & $\begin{array}{l}\text { Система стандартизації галузі зв'язку України. Порядок проведення } \\
\text { науково-дослідних робіт. Загальні положення }\end{array}$ \\
\hline КНД 45-004-98 & $\begin{array}{l}\text { Система стандартизації галузі зв’язку України. Порядок проведення } \\
\text { дослідно-конструкторських робіт. Загальні положення }\end{array}$ \\
\hline КНД 45-005-98 & $\begin{array}{l}\text { Система стандартизації галузі зв’язку України. Порядок розроблення } \\
\text { галузевих стандартів }\end{array}$ \\
\hline КНД 45-006-98 & $\begin{array}{l}\text { Система стандартизації галузі зв’язку України. Порядок розроблення } \\
\text { технічних умов на продукцію зв'язку }\end{array}$ \\
\hline КНД 45-011-96 & $\begin{array}{l}\text { Галузева система стандартизації Міністерства зв’язку України. } \\
\text { Планування робіт зі стандартизації }\end{array}$ \\
\hline ДСТУ 2621-94 & $\begin{array}{l}\text { Зв’язок телефонний. Загальні поняття. Телефонні мережі. Терміни та } \\
\text { визначення }\end{array}$ \\
\hline ДСТУ 2624-94 & Зв’язок телефонний. Системи сигналізації. Терміни та визначення \\
\hline ДСТУ 3773-98 & Мережа зв’язку цифрова первинна. Терміни та визначення \\
\hline ДСТУ 3774-98 & Система зв’язку єдина національна. Терміни та визначення \\
\hline КНД 45-067-97 & $\begin{array}{l}\text { Нормативи показників якості обслуговування викликів і якості } \\
\text { встановлених телефонних з'єднань у телефонній мережі загального } \\
\text { користування України }\end{array}$ \\
\hline КНД45-080-2001 & $\begin{array}{l}\text { Апаратура почасового обліку місцевих телефонних розмов. Основні } \\
\text { параметри і загальні технічні вимоги }\end{array}$ \\
\hline
\end{tabular}


Оскільки в Україні відсутня чітка політика в галузі стандартизації засобів та послуг зв'язку, то зустрічається значне відставання в розробці національних стандартів від вимог технологій, що імпортуються із західних країн.

Об'єкт дослідження. Із-за відсутності необхідних національних стандартів під час проектування, сертифікації, експлуатації мереж та обладнання зв'язку в Україні широко використовуються рекомендації ITU i стандарти ETSI. Однак використовуються насамперед стандарти ETSI $з$ таких причин. По-перше, стандарти ETSI узгоджені з нормативними документами інших міжнародних і європейських організацій. По-друге, Україна визначила курс на вступ до Свропейського Союзу, а це вимагає в області стандартизації перенесення європейських стандартів на національний рівень.

Робота в міжнародних організаціях на етапах обговорення та ухвалення проектів стандартів може полегшити та прискорити розробку національних стандартів шляхом переносу стандартів, отримавши статус міжнародних або європейських, на національний рівень.

Для того, щоб визначити, як необхідно сьогодні і в найближчому майбутньому формувати політику стандартизації українських мереж, потрібно врахувати світовий досвід [2].

В розвинутих країнах оператор телекомунікаційної мережі $\epsilon$ доволі самостійним, а його обов'язки по відношенню до абонента i мережі загального користування визначаються виданою йому ліцензією (де зазначається якість запропонованих послуг), а також міжоператорськими договорами. Тому, якщо оператор забезпечує виконання умов в цих документах, він має право сам вибирати внутрішньомережні технології, стандарти і обладнання. Простіше кажучи, неважливо, що відбувається всередині його мережі, важливо забезпечити виконання висунутих до неї вимог. 3 цієї причини, наприклад, в країнах $Є \mathrm{C}$ не існує видачі сертифікатів на мережне обладнання оператора (комутаційні станції, системи передачі тощо). В основу політики підтвердження відповідності покладено перевірку на межі мережі (термінал користувача - мережа). Підключення до мережі загального користування повинно відбуватися 3 використанням основних вимог iз забезпечення безпеки, інтегрованості мережі, захисту даних тощо, які викладені в Директивах Європейської комісії (1995/5/СС, 98/10/СС і ін.). Ці основні вимоги повинні бути конкретизовані відповідними стандартами. В країнах ЄС сьогодні існує перелік гармонізованих технічних норм (Перелік 2002/3 331/04), які охоплюють такі напрямки: 
- $\quad$ орендовані лінії;

- доступ до мереж і міжмережна взаємодія;

- $\quad$ багатооператорський доступ до мережі на абонентському відділі;

- $\quad$ надання послуг;

- $\quad$ захист даних;

- $\quad$ мережа для розподілу послуг мовлення.

Ці стандарти не є обов'язковими до використання і слугують для підтримки послуг, інтерфейсів, мережних функцій, що дає змогу забезпечити взаємодію послуг, а користувачу - можливість вибору. Однак в цьому ж переліку виділений набір стандартів і специфікацій, виконання яких $\epsilon$ обов'язковим в рамках, визначених Директивами СС. Це - стандарти i специфікації, які відносяться до орендованих ліній (аналогові двопровідні і чотирипровідні лінії звичайної і спеціальної якості, цифрові канали 64 Кбіт/с і первинні цифрові тракти 2048 Кбіт/с (Директива 92/44/ССС), а також якість надаваних послуг (Директива 98/10/СС зі змінами і доповненнями)). Виділено дев'ять параметрів, що визначають якість телефонного обслуговування (час встановлення з'єднання, коефіцієнт непройдених викликів, час відповіді довідкової служби, точність розрахунків з користувачами тощо).

Сьогодні на українському ринку телекомунікацій діє багато стандартів, розроблених ще під час існування колишнього Радянського Союзу. Із-за відсутності фінансування в достатньому обсязі створення нових стандартів відбувалося дуже повільно. В результаті відсутні національні стандарти 3 багатьох нових технологій (WDM, IP, OMTS, CDMA тощо). Для того, щоб вийти 3 такого становища, замість них на практиці використовуються рекомендації, стандарти i специфікації міжнародних організацій, які займаються стандартизацією.

На сьогодні Україну в ETSI представляють два дійсних члени:

1. Український науково-дослідний інститут зв'язку.

2.Український науково-дослідний інститут радіо і телебачення.

Основою правової бази функціонування сфери телекомунікації є Закони України «Про телекомунікації», «Про радіочастотний ресурс України», «Про електронні документи та електронний документообіг», «Про електронний цифровий підпис» та постанова Кабінету Міністрів України від 29 червня 2004 p. № 812 «Деякі питання оперативно-технічного управління телекомунікаційними мережами в умовах надзвичайних ситуацій, надзвичайного та воєнного стану».

Також в Україні діє «Положення про порядок отримання прав i 
підготовки до голосування (схвалення) в Європейському інституті стандартів зв'язку (ETSI)». Це положення встановлює процедуру голосування за документи ETSI, незалежно від їх типу, форми, назви та скерованості, а також порядок виконання підготовчих робіт, надання прав для голосування i подальшого використання в Україні прийнятих стандартів.

Документація ETSI виноситься на голосування довіреною особою від імені Адміністрації зв'язку України. Пропозиція щодо голосування направляється підприємствами, організаціями i відомствами України в Координаційну раду Державного комітету зв'язку і інформатизації України через Управління міжнародних зв'язків.

В пропозиції обгрунтовується необхідність для України конкретного документа ETSI, визначаються можливі політичні, правові, матеріальні і фінансові результати впровадження документа, вказуються суб'єкти реалізації документа. Координаційна рада розглядає пропозицію і не пізніше ніж в місячний термін повертає їх заявнику разом з відповідними висновками.

Впровадження у галузі зв'язку стандарту ETSI, якому надано право дії як нормативного документа України, здійснюється в порядку і за процедурами, встановленими Державним комітетом зв'язку та інформатизації України.

Методи дослідження. При здійсненні аналізу ринків телекомунікаційних послуг, основних положень державних i світових стандартів, інших нормативних документів щодо технічних засобів телекомунікацій використовували методи збору інформації, методи аналізу та статистичні методи, основані на збиранні та обробці формалізованих даних звітності.

Виклад основного матеріалу дослідження з повним обгрунтуванням отриманих наукових результатів. Вимоги державних і галузевих стандартів, інших нормативних документів щодо технічних засобів телекомунікацій $\epsilon$ обов'язковими для всіх виробників i постачальників технічних засобів, науково-дослідних, проектних та будівельних організацій, а також для операторів, провайдерів телекомунікацій. Вимоги до якості послуг $\epsilon$ обов'язковими для операторів, провайдерів телекомунікацій, що надають телекомунікаційні послуги на території України. Галузеві стандарти розробляються та затверджуються відповідно до законодавства України про стандартизацію 3 урахуванням стандартів та рекомендацій міжнародних організацій. Відповідно до статті 15 Закону України «Про телекомунікації» впровадження технічної політики у сфері надання телекомунікаційних послуг, стандартизації, підтвердження відповідності технічних засобів телекомунікацій, організація та відповідальність за розроблення стандартів у 
сфері телекомунікацій відноситься до компетенції центрального органу виконавчої влади в галузі зв'язку.

На даний час, в країнах СС використовується стандарт Технічного комітету Свропейського інституту стандартизації - ETSI 202057, який стосуються визначення переліку параметрів якості послуг, методів їх вимірювання та оцінювання. Стандарт поділений на чотири частини (табл. 2).

Таблиця 2

Частини стандарту ETSI 202057

\begin{tabular}{|c|c|}
\hline перша частина & $\begin{array}{c}\text { загальна, визначені в ній параметри якості послуг можуть бути } \\
\text { застосовані для усіх видів телекомунікаційних послуг } \\
\text { ETSI ES } 202 \text { 057-1 }\end{array}$ \\
\hline друга частина & $\begin{array}{c}\text { визначає параметри якості послуг голосової телефонії, факсимільного } \\
\text { зв’язку, послуг модемної передачі даних та коротких повідомлень } \\
\text { (SMS) ETSI EG } 202 \text { 057-2 }\end{array}$ \\
\hline третя частина & $\begin{array}{c}\text { визначає параметри якості послуг, що специфічні для мобільного } \\
\text { зв’язку ETSI EG } 202 \text { 057-3 }\end{array}$ \\
\hline $\begin{array}{l}\text { четверта } \\
\text { частина }\end{array}$ & $\begin{array}{c}\text { визначає параметри якості послуг доступу до Інтернету } \\
\text { ETSI EG } 202 \text { 057-4 }\end{array}$ \\
\hline
\end{tabular}

Зміни в державному регулюванні повністю узгоджуються із оновленою нормативно-правовою базою щодо національних стандартів України. Детально ознайомитись із особливостями застосування ДСТУ ETSI EG 202057-4:2015 для послуг доступу до мережі можна в презентації Державного університету телекомунікацій.

Організація контролю якості послуг під час проведення заходів державного нагляду визначена «Порядком здійснення державного нагляду за ринком телекомунікацій».

3 метою забезпечення належного захисту прав споживачів та надання допомоги операторам, провайдерам телекомунікацій при розробці та укладенні договорів НКРЗІ затверджені «Основні вимоги до договору про надання телекомунікаційних послуг», якими враховані пропозиції операторів, провайдерів телекомунікацій та споживачів щодо вдосконалення договору. Даним документом передбачено, зокрема, вимогу щодо чіткого визначення у договорі значень показників якості та/чи інших технічних параметрів надання послуг, які не можуть бути гіршими від встановлених відповідними нормативно-правовими актами у сфері телекомунікацій. Тому НКРЗІ приділяє 
особливу увагу перевірці, а при виявленні порушень, вживає заходів щодо приведення договорів про надання телекомунікаційних послуг у відповідність Основним вимогам до договору та Правилам надання та отримання телекомунікаційних послуг [3,4].

Відповідно до законодавства в телекомунікаційних мережах усіх форм власності необхідно передбачити захист технічних засобів та інформації, що ними передається [3-6]. Для забезпечення захисту інформації в телекомунікаційних мережах слід виконати такі завдання:

- створення i поступове впровадження нормативно-правової бази із забезпечення питань технічного та криптографічного захисту інформації, гармонізованого з європейськими та міжнародними стандартами;

- розроблення сучасних методів захисту інформації на базі технічних засобів для комплексного розв'язання завдань забезпечення захисту інформації в телекомунікаційних мережах;

- створення системи легального перехоплення інформації у телекомунікаційних мережах у випадках, передбачених законодавством;

- створення державного координаційного центру 3 питань безпеки в інформаційно-телекомунікаційних мережах загального користування, сприяння створенню державних та недержавних центрів компетенції та реагування на інциденти в телекомунікаційних мережах.

Висновки та перспективи подальших досліджень. Отже, для подальшого розвитку стандартизації телекомунікаційних послуг необхідно залучення зовнішніх та внутрішніх інвестицій для розвитку телекомунікаційних мереж у сільських, гірських місцевостях і депресивних регіонах, сприяння структурним, технічним і технологічним перетворенням у сфері телекомунікацій, підвищенню ефективності регуляторного впливу на ринок телекомунікацій 3 використанням рекомендацій міжнародних організацій.

\section{Список використаних джерел}

1. Звіт щодо діяльності НКРЗ та стану телекомунікацій в Україні за 2017 p. [Електронний ресурс] / Національна комісія з питань регулювання зв'язку України. Режим доступу: http://www.nkrz.gov.ua/ img/zstored/File/2011_zvit_nkrz.pdf.

2. Аникин О.Б. Мировой рынок телекоммуникаций: современные тенденции, стратегии и перспективы развития [Текст]: монография / О.Б. Аникин . - М.: ГУУ, 2009. $170 \mathrm{c}$.

3. Про телекомунікації: Закон України [електр. ресурс] // Режим доступу: https://zakon.rada.gov.ua/laws/show/1280-15. 
4. Про затвердження порядку аналізу ринків послуг пропуску трафіка та визначення операторів телекомунікацій з істотною ринковою перевагою: Постанова Кабінету Міністрів України [Електронний ресурс]. - Режим доступу : https://zakon.rada.gov.ua/laws/show/z107811.

5. Апопій В.В. Організація і технологія надання послуг / В.В. Апопій, I.I. Олексин, Н.О. Шутовська, Т.В. Футало. - Л.: Академія, 2006. - 312 с.

6. Самойленко А.А. Технологія та контроль за якістю надання послуг: навч. посіб. / А.А. Самойленко. - К.: Київ. нац. торг.-екон. ун-т, 2003. - 244 с.

Цель. Исследование государственной нормативно-законодательной базы в сфере телекоммуникационных услуг с иелью их эффективного развития.

Методика. При исследовании использовали базу действующих государственных и отраслевых стандартов и других нормативных документов, определяющиих требования к телекоммуникачионным сетям, их технических средств и качества телекоммуникационных услуг.

Результаты. Из-за отсутствия необходимых национальных стандартов при проектировании, сертификации, эксплуатации сетей и оборудования связи в Украине широко используются рекомендации ITU и стандарты ETSI. Работа в международных организачиях на этапах обсуждения и принятия проектов стандартов может облегчить и ускорить разработку начиональных стандартов путем переноса стандартов, получив статус международных или европейских, на национальный уровень.

Для того, чтобы определить, как необходимо сегодня и в ближайшем будущем формировать политику стандартизации украинских сетей, нужно учесть мировой опыт. Подключение к сети общего пользования должно происходить с использованием основных требований по обеспечению безопасности, интегрированности сети, защиты данных и т.д., которые изложены в директивах Европейской комиссии (1995/5 / EC, 98/10 / EC и др.) Эти основные требования должны быть конкретизированы соответствующими стандартами. В странах ЕC сегодня существует перечень гармонизированных технических норм (Перечень 2002/3 331/04), которые охватывают следуюшие направления: арендованные линии, доступ к сетям и межсетевое взаимодействие,доступ к сети на абонентском отделе большому количеству операторов, оказание услуг, защита данных, сеть для распределения услуг вещчания.

В ходе исследования выявлено, что на украинском рынке телекоммуникаций действует много стандартов, разработанных еще во время существования бывшего Советского Союза. Из-за отсутствия финансирования в достаточном объеме отсутствуют национальные стандарты по многим новых технологий (WDM, IP, OMTS, CDMA и т.n.). Для обеспечения эффективного развития телекоммуникационных услуг необходимо создать и постепенно внедрить нормативно-правовую базу по обеспечению вопросам технической и криптографической защиты информачии, гармонизированного с европейским и международным стандартам.

Научная новизна. Установлена и обоснована необходимость гармонизации требований государственных стандартов в соответствии $\kappa$ требованиям международных нормативных документов, а также совершенствования системь стандартизации телекоммуникационных услуг с учетом мирового опыта.

Практическая значимость. Подробно проанализированы и раскрыты основные средства государственного регулирования и защиты рынка телекоммуникаций. Проведенный анализ выявил направления развития системь стандартизации телекоммуникационных услуг. 
Ключевые слова: телекоммуникации, стандартизация, телекоммуникационные услуги, стандарты, Интернет.

Purpose. Research of state normatively-legislative base in the field of telecommunication services with an aim them effective development.

Methodology. At research used the base of operating state and branch standards and other normative documents which determine requirements to TCNS, them hardwares and quality of telecommunication services.

Findings. Due to the lack of necessary national standards in the design, certification, and operation of networks and equipment in Ukraine, ITU recommendations and ETSI standards are widely used. Working with international organizations will facilitate and speed up the development of national standards through the transfer of international or European standards to the national level.

In order to determine if it is necessary today and in the near future to create a policy for standardization in Ukrainian networks, it is important to take into account international experience. The connection to the public network should take place using the basic requirements for security, network integration, data protection etc., as stated in the European Commission's Directives (1995/5 / EU, 98/10 / EU, etc.). These basic requirements should be specified by the relevant standards. In the EU, today there is a list of harmonized technical regulations (List 2002/3 331/04) covering the following areas: leased lines, access to networks and interconnection, multi-operator access to the network at the subscriber's department, provision of services, data protection, network for distribution of speech services.

It was discovered during study that many standards which have been used on the Ukrainian telecommunications market were developed during the existence of the former Soviet Union. Due to the lack of funding, there are not enough national standards for many new technologies (WDM, IP, OMTS, CDMA, etc.). In order to ensure the efficient development of telecommunication services, it is necessary to create and gradually introduce a legal and regulatory framework harmonized with European and international standards for the provision of technical and cryptographic information protection issues.

Originality. The article established and substantiated the necessity of harmonization of the requirements of the state standards with the requirements of the international regulatory documents. The article also shows the necessity of improvement of the standardization system of telecommunication services and the importance of taking into account the world experience while developing new standards.

The practical value. The main means of state regulation and protection of the telecommunication market are thoroughly analyzed and disclosed. The analysis revealed the directions of development of the telecommunication services and the standardization system.

Key words: telecommunications, standardization, telecommunication services, standards, Internet.

Стаття рекомендована до друку доктором технічних наук, професором Херсонського НТУ Тіхосовою Г.А. Дата надходження в редакиію 11.02.2019 p. 